\title{
Artery and Subclavian Vein Injury due to Blunt Trauma: A Case Report and Literature Review
}

\author{
Juliane Rocha Bertelli Cabral ${ }^{1} \odot$, Karina Cavalcante da Silva ${ }^{2} \odot$, Isabella Aurea Signorini ${ }^{3} \odot$, Danielle Gonçalves de \\ Carvalho Pinheiro $^{4}{ }^{\circ}$, Arthur Alencar Raposo Tenorio ${ }^{5}{ }^{\circ}$, Joao Victor Pinheiro Nunes ${ }^{6}$, Ana Carolina Teixeira ${ }^{7}$, Paloma

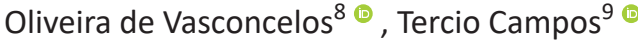

\begin{abstract}
Aim and objective: To report the case and the clinical-surgical evolution of a patient after blunt cervical-thoracic trauma that resulted in fracture of the clavicle, injury to the subclavian artery and vein and almost total avulsion of the brachial plexus, as well as perform a literature review.

Background: Vascular injury to the subclavian artery and vein through blunt trauma is rare. In blunt trauma, you run into an accident of high enough energy to injure the various structures that protect these vessels. Detailed anamnesis and physical examination are essential for elucidating the case, and imaging exams are excellent adjuvants in the decision-making process in these cases.

Case description: A 33-year-old woman, victim of a collision of a motorcycle and a light pole, is referred to a secondary health service, where she develops ischemia of the left upper limb, associated with a fractured clavicle and brachial plexus injury. Patient underwent vascular and orthopedic surgery, respectively. The patient evolved with good general condition, good left upper limb perfusion and lack of sensitivity and movement of the limb.

Conclusion: The evaluation of the case and the studies surveyed showed the complexity of the condition, making an assertive diagnosis and early approach to vascular lesions of the subclavian vessels essential, in order to obtain satisfactory results.

Clinical significance: The rarity associated with the high complexity of subclavian vessel injury, as well as its high mortality when not detected quickly and correctly, makes this case report relevant to the scientific community, since its exposure is related to the literature review allows sharing important knowledge about the subject.
\end{abstract}

Keywords: Blunt trauma, Subclavian artery, Vascular injury.

\section{RESUMO}

Objetivo: Relatar o caso e a evolução clínico-cirúrgica de uma paciente após trauma fechado cérvico-torácico que resultou na fratura da clavícula, lesão da artéria e veia subclávias e avulsão quase total do plexo braquial, bem como realizar uma revisão de literatura.

Introdução: A lesão vascular de artéria e veia subclávia por meio de trauma fechado é rara. Em traumas fechados, corre em acidente de energia alta o suficiente para lesionar as diversas estruturas que protegem esses vasos. A anamnese e o exame físico detalhados são essenciais para a elucidação do caso, e os exames de imagem são excelentes adjuvantes na tomada de conduta frente a estes casos.

Descrição do caso: Mulher, 33 anos de idade, vítima de colisão moto versus poste, é encaminhada para serviço de saúde secundário, onde evolui com isquemia de membro superior esquerdo, associada a fratura de clavícula e lesão de plexo braquial. Paciente foi submetida a cirurgia vascular e ortopédica, respectivamente. Evoluiu com bom estado geral, boa perfusão de MSE e ausência de sensibilidade e movimentação do mesmo. Conclusão: A avaliação do caso e estudos levantados evidenciaram a complexidade do quadro, tornando fundamental o diagnóstico assertivo e abordagem precoce das lesões vasculares dos vasos subclávios, a fim de se obter resultados satisfatórios.

Significância clínica: A raridade associada a alta complexidade da lesão de vasos subclávios, assim como a sua alta mortalidade quando não detectada de forma rápida e correta, torna o presente relato de caso relevante para a comunidade cientifica, uma vez que sua exposição, relacionada com a revisão de literatura permite compartilhar importante conhecimento acerca do assunto.

Palavras-chave: Artéria Subclávia, Lesão vascular, Trauma fechado.

Panamerican Journal of Trauma, Critical Care \& Emergency Surgery (2021): 10.5005/jp-journals-10030-1350

\section{BACKGROUND}

Vascular trauma occurs through the destruction of blood vessels that supply important areas of the body, so that this loss of integrity can abruptly interrupt the supply of oxygen to tissues and generate serious consequences. ${ }^{2}$

Injuries to the subclavian vein and/or artery are, especially in cases of blunt trauma, relatively uncommon episodes because they are vessels of short extension and because the anatomical location of this system is protected by a series of osteoarticular structures, ${ }^{2}$ in addition to the subclavian musculature and the deep cervical fascia. Therefore, for a vascular injury to occur in this region, a high-energy impact is needed ${ }^{1,3}$ usually associated with a fracture of the clavicle.

\footnotetext{
${ }^{1-9}$ Department of General Surgery, General Hospital of Itapecerica da Serra, Itapecerica da Serra-SP, Brazil

Corresponding Author: Juliane Rocha Bertelli Cabral, Department of General Surgery, General Hospital of Itapecerica da Serra, Itapecerica da Serra-SP, Brazil, Phone: +55(13)99775-7913, e-mail: julianebertelli@ hotmail.com

How to cite this article: Cabral JRB, da Silva KC, Signorini IA, et al. Artery and Subclavian Vein Injury due to Blunt Trauma: A Case Report and Literature Review. Panam J Trauma Crit Care Emerg Surg 2021;10(3):126-129.
}

Source of support: Nil

Conflict of interest: None

\footnotetext{
(OThe Author(s). 2021 Open Access This article is distributed under the terms of the Creative Commons Attribution 4.0 International License (https://creativecommons. org/licenses/by-nc/4.0/), which permits unrestricted use, distribution, and non-commercial reproduction in any medium, provided you give appropriate credit to the original author(s) and the source, provide a link to the Creative Commons license, and indicate if changes were made. The Creative Commons Public Domain Dedication waiver (http://creativecommons.org/publicdomain/zero/1.0/) applies to the data made available in this article, unless otherwise stated.
} 
The pattern of vascular injury ranges from transient spasm to complete laceration. And, in decreasing order of frequency, the affected vessels are: subclavian artery, subclavian vein and internal jugular vein. ${ }^{4}$ Subclavian artery injury is suspected when there is trauma in the upper third of the chest wall, in the topography of the clavicle or supraclavicular fossa associated with the absence or decrease of the pulse in the upper limb, hemorrhage, local hematoma, shock by massive hemothorax and fracture of the first rib. $^{5}$ In about $20 \%$ of cases, both the artery and vein are injured, while the brachial plexus is affected in up to $1 / 3$ of them. ${ }^{5}$

The present report is about a female patient, 33 years old, victim of a traffic accident, admitted by the general surgery team of the General Hospital of Itapecerica da Serra (HGIS) after multiple trauma. Once the diagnosis of complete avulsion of the subclavian vessels and brachial plexus was established, the vascular surgery team together with the orthopedics surgically addressed the condition, preserving the affected limb.

The work has great relevance due to the infrequency in the literature and the complex surgical skill required for its correction, in addition to the need to accurately diagnose the lesion and direct the treatment in order to ensure a good evolution of the patient.

\section{Case Description}

A 33-year-old female patient was admitted to the Hospital of Itapecerica da Serra (HGIS)-Itapecerica da Serra/SP brought by firefighters, victim of a motorcycle versus light pole accident, with a helmet, in an ethylic state. Admitted by the general surgery team, she reported pain in her left shoulder, upper hemithorax on the left, and cervical and maxillary regions on the left.

Initial care according to the protocol determined by the Advanced Trauma Life Support (ATLS) did not present significant changes at first, with the patient being hemodynamically stable, with the cervical region on the left swollen, in addition to the presence of ecchymosis and abrasions. It also contained hematoma and deformation in the clavicular region of the same antimere, associated with massive edema and hematoma in the left shoulder girdle with crackling in the region of the clavicle and scapula. The affected limb's pulses were present.

After performing the initial care for the multiple trauma patient, an orthopedic assessment was requested and CT scans of the skull, face, chest, left shoulder, cervical, thoracic and lumbar spine, upper abdomen and pelvis were performed. The following were found: diaphyseal fracture of the left clavicle; fracture of the body and acromion of the left scapula; fracture of the spinous process from $\mathrm{T} 2$ to $\mathrm{T} 4$.

The team chose to keep the patient under neurological surveillance. On further evaluation, the patient evolved with decreased radial, ulnar and axillary pulses in the ESM, cyanosis, hypothermia and sensory and motor deficits in the affected left upper limb, raising the hypothesis of trauma to the blood vessels at the level of the shoulder and arm, and of the brachial plexus. Computed tomography angiography of the left upper limb was requested (Fig. 1).

A surgical approach for revascularization of the injured limb was then indicated by the vascular surgery team (Fig. 2), arterial exploration performed, distal embolectomy, ligation of the proximal and distal stump of the subclavian vein, and bypass in the left subclavian artery with the great saphenous vein of the left lower limb, by subclavicular access with extension of the furcula to the axillary region of the left upper limb, with success. At the same surgical time, orthopedics performed osteosynthesis of the left clavicle with a bridge plate and plexus exploration of the left brachial plexus, which was found practically avulsed, with only one proximal stump available, probably from the inferior trunk, neurotized to the lateral and posterior cord.

After the surgical procedures, the patient remained in the ICU bed, remaining hemodynamically stable, without the need for ventilatory support and vasoactive drug (VAD). The left upper limb did not show signs of ischemia and cyanosis, maintained pulses and lack of sensitivity and movement. The patient was discharged from the ward with follow-up guidance.

\section{Discussion}

Traumatic vascular injuries involving the region of the subclavian vessels are uncommon, representing 1 to $9 \%$ of cases, and of these, approximately $90 \%$ result from penetrating wounds and only $5 \%$ originate from the blunt trauma mechanism. ${ }^{6-11}$

According to Costa, Robbs $^{8}$ (1988), when following 167 patients for 6 years with lesions of the subclavian/mediastinal vessels, only $9 \%$ were due to blunt trauma, isolated arterial, with brachial plexus avulsion or rib and/or clavicle fractures always associated, as occurred in the present study.

The infrequency of this type of injury is precisely because blunt trauma, to affect these vessels, must be of high energy, and therefore has high morbidity and mortality, generating in up to $60 \%$ of cases the death of victims even in the pre-hospital environment. In addition, when there is the possibility of surgically approaching the patients, the death rate contemplates another $5-30 \%{ }^{12}$ and the permanence of sequelae is recurrent.

The diagnosis in these conditions can be difficult due to the abundant collateral circulation in the region that prevents acute ischemia. ${ }^{13}$ On physical examination, it is possible to find a difference in blood pressure measured greater than $15 \mathrm{~mm} \mathrm{Hg}$ between the upper limbs, distal cyanosis, coldness of the extremities, decreased or non-existent pulse in the affected arm and the absence of these findings in the initial evaluation, as occurred with the patient, delays the diagnosis. ${ }^{14}$ In clinical suspicion, therefore, it is essential to

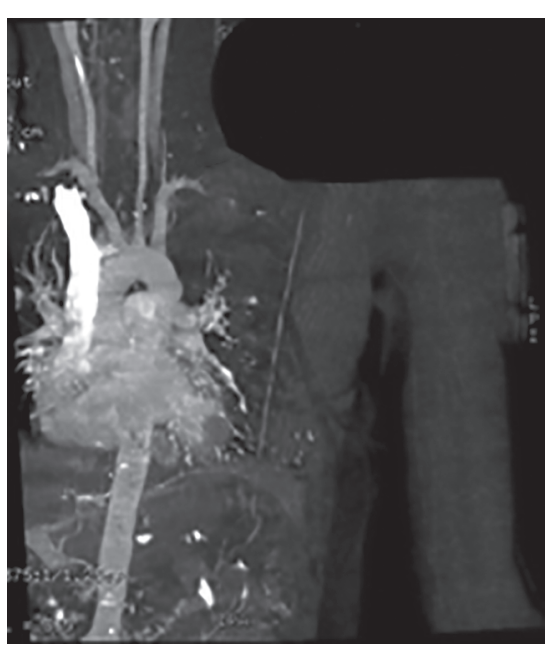

Fig. 1: Computed tomography angiography of left upper limb joints showing laceration of the left subclavian artery in a supraclavicular situation, not characterizing adequate contrasting of arterial branches distally. Adequate contrasting of the venous structures was not characterized, due to probable hypoflow of the limb 


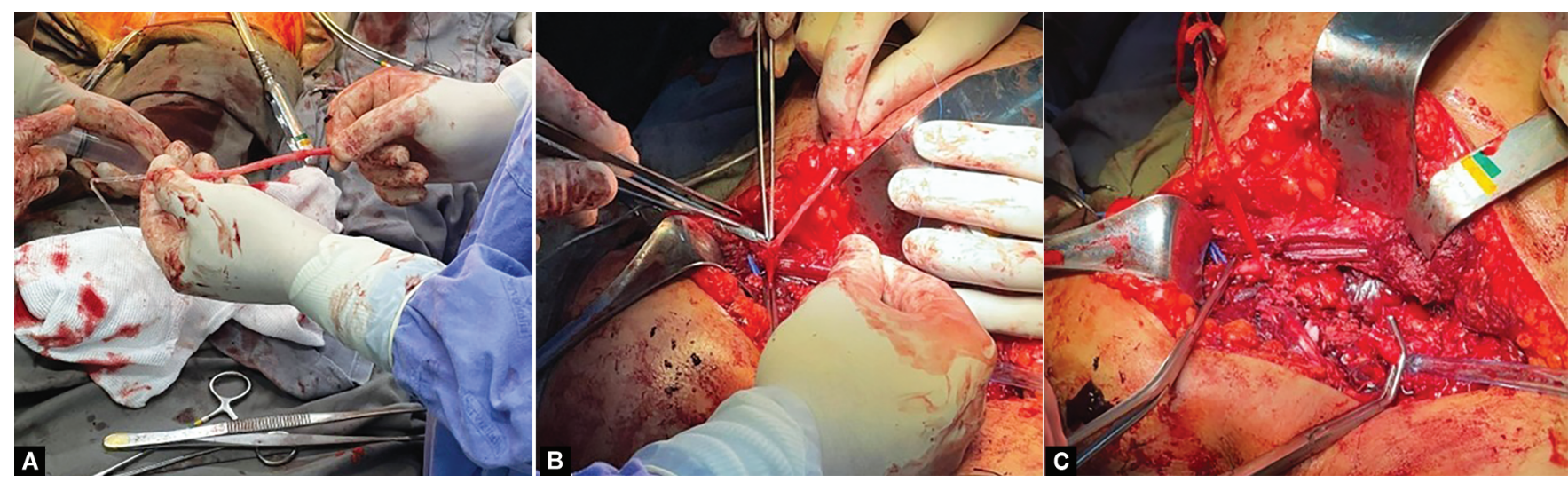

Figs 2 A to C: (A) Distal and proximal left subclavian artery stump; (B) Inverted great saphenous vein graft; (C) Terminal-end distal anastomosis of inverted great saphenous vein and left subclavian artery

request a chest $X$-ray, looking for possible fractures. The ankle-arm index $(\mathrm{ABI})$ can be useful in measuring circulation in young patients with extremity injuries. Doppler echocardiography is another option, despite angiography being the gold standard for evaluation in stable patients to confirm the event and aid in surgery. ${ }^{15}$

In general, the adequate treatment of subclavian injury depends on its mechanism and extension. These patients often present with massive hemorrhage and require extensive resuscitation and emergency surgical management. ${ }^{16}$

Once a surgical approach is necessary, the crucial decision is which technique will be more successful, with the least wasted time and unnecessary or ineffective incisions, in an attempt to reach the affected site. ${ }^{16}$ Elkbuli et al. ${ }^{17}$ (2019) cited in their study the access routes to the subclavian artery, such as thoracotomy and median or limited sternotomy, and as for surgical repairs, the options are end-to-end anastomosis, lateral arteriorrhaphy with ligation, autologous veins (saphenous vein) or prosthetics and angioplasty. In severe cases, a temporary intravascular shunt can be implanted until stabilization is achieved and, in extreme cases, the subclavian artery can be linked with a low risk of ischemia. ${ }^{15}$

In the case presented here, a subclavicular incision with extension of the furcula to the axillary region of the upper left limb was chosen, with repair through bypass of the inverted saphenous vein in the left subclavian artery, consisting of the most frequent vascular repair, in addition to the lower association with infection in the postoperative period. ${ }^{18}$ Synthetic grafts should be reserved for cases with disproportionate sizes, extensive lesions and need for less surgical time.

According to Costa-Val et al. ${ }^{19}$ in a prospective study of care for 1000 patients in a civil cardiovascular trauma center, $3 \%$ of arterial injuries were caused by the subclavian artery, while $1.4 \%$ of the venous injuries were caused by the subclavian vein. Regarding the treatment adopted, in $91 \%$ of arterial injuries, primary suture, interposition and/or bypass (venous and/or synthetic) were performed, whereas primary venous ligation was the procedure of choice for venous lesions in most of the cases (57.6\%).

Hoff et al. ${ }^{20}$ evaluated 21 cases of lesions in the brachiocephalic or subclavian arteries and, of these, 8 were due to blunt trauma and 13 to penetrating. Twenty patients underwent surgery and bypass was the most used technique for blunt injuries, while primary repair was the preferred choice for penetrating ones, which had a preoperative evaluation time of 66 minutes, evolved in greater numbers in an unstable way (38\% of deaths), opposing the 319 minutes of the other group that had a null mortality rate.
In more complex lesions, with the possibility of approximation of the stumps without tension, we can opt for resection of a maximum of $1 \mathrm{~cm}$ of vessel with end-to-end anastomosis. Thus, for every $1 \mathrm{~cm}$ of artery removed, it is necessary to mobilize $3 \mathrm{~cm}$ of the artery so that there is no tension in the anastomosis. However, if the lesion is larger than $1 \mathrm{~cm}$, it may be necessary to make a bridge, with the saphenous vein being the ideal replacement. ${ }^{1}$ In the presence of tension in the primary anastomosis, the chances of rupture and/or thrombosis of the repaired vessel are greater. That being said, an interposition or bypass graft should be used, preferably using autologous tissue in the repair. ${ }^{3}$

It is important to emphasize that, when approaching arterial injuries, it is essential that the entire intima layer is inspected, especially in situations where its rupture occurs to a greater extent than initially assumed. Upon diagnosis or suspicion of secondary thrombi, proximal and distal thrombectomy, followed by proximal and distal regional heparinization should be performed. Except for contraindications, systemic heparinization is indicated. ${ }^{3}$

In the immediate postsurgery period, thrombosis and bleeding are common complications, the first of which is caused by a defect in the restoration technique, which includes anastomotic stenosis or incomplete debridement of the injured site. ${ }^{3}$

In cases of venous lesions, primary repair is recommended as long as it does not cause stenosis or the need for a graft, otherwise, a terminal ligation is chosen, which, in the involvement of the upper limb, does not generate major repercussions due to compensation for collateral circulation. ${ }^{18}$

The endovascular approach is a valid technique and defended as the first choice for stable patients, but contraindicated in cases of infected wounds, aero-digestive injuries, airway or brachial plexus compression, uncontrollable active bleeding, ischemia with risk of limb loss, excessive luminal discrepancy between the site of proximal and distal arterial involvement or inability to cross the lesion with a guide wire. ${ }^{21-23}$ In the case presented, this procedure was unfeasible due to the total avulsion of the vessel.

\section{Conclusion}

The almost total avulsion of the brachial plexus resulting from the high impact suffered by the patient impaired the limb's function, since its sensitivity and motricity remained absent even after surgical correction. This shows that, despite the success obtained by vascular surgery in the perfusion of the left upper limb, the concomitant involvement of other structures can result in permanent sequelae, such as a dysfunctional limb. 
We conclude that the repair of lesions in the subclavian artery is challenging because, in addition to the difficulty in accessing it, it requires precision in its diagnosis and handling. In addition, solid knowledge of the anatomy and a prepared operating room, associated with the planning of the procedure and the experience of the team, are essential to maximize the chances of success of the approach, since there are imminent risks in all surgical accesses available for correction of this type of injury.

\section{ORCID}

Juliane Rocha Bertelli Cabral ๑ https://orcid.org/0000-0003-2625-5637 Karina Cavalcante da Silva ๑ https://orcid.org/0000-0002-3894-0386 Isabella Signorini $\odot$ https://orcid.org/0000-0002-0749-4459

Danielle Goncalves de Carvalho Pinheiro (c) https://orcid. org/0000-0002-0504-0648

Arthur Alencar Raposo Tenorio $\odot$ https://orcid.org/0000-0003-4545-0112 Ana Carolina Teixeira ๑ https://orcid.org/0000-0003-1590-7679

Paloma Oliveira Vasconcelos $\odot$ https://orcid.org/0000-0001-9607-4351

Tercio Campos ๑ https://orcid.org/0000-0002-3927-4530

\section{References}

1. Ribeiro Jr, MAF. Fundamentos em cirurgia do trauma. 1. ed. Rio de Janeiro: Roca; 2016.

2. Silva SA. Emergência e urgência em cirurgia vascular: um guia prático. 1. ed. Barueri: Manole; 2018.

3. Abib SCV, Perfeito JAJ. Guias de medicina ambulatorial e hospitalar da UNIFESP-EPM: trauma. 1. ed. Barueri: Manole; 2012.

4. Coulier B, Mairy Y, Etienne PY, et al. Diagnostic Tardifd' pseudo aneurysm traumatique de l'ar tère sous-claviere. J Belge Radiol 1996;79:26-28. ISBN: 978-2-294-73544-8.

5. Lederman A, Paiva F, Saes HM, et al. Ferimentos da artéria subclávia. Estudo retrospectivo de 20 casos. J Vasc Br 2005;4(2):149-154. Disponivel em: https://www.jvascbras.org/article/5df132a70e8825 407db5f736

6. Rich N, Hobson R, Jarstfer B, et al. Subclavian artery trauma. Jtrauma 1973;13(6):485-496.DOI:10.1097/00005373-197306000-00001

7. Graham JM, Feliciano DV, Mattox KL, et al. Management of subclavian vascular injuries. J trauma 1980;20(7):537-544. DOI: 10.1097/00005373-198007000-00001

8. Costa MC, Robbs JV. Nonpenetrating subclavian artery trauma. J VasC Surg 1988;8(1):71-75. DOI: 10.1067/mva.1988.avs0080071

9. Lin PH, Koffron AJ, Guske PJ, et al. Penetrating injuries of subclavian artery. Am J Surg 2003;185(6):580-584. DOI: 10.1016/s00029610(03)00070-9
10. McKinley AG, Carrim AT, Robbs JV. Management of proximal axillary and subclavian artery injuries. Br J Surg 2000;87(1):79-85. DOI: 10.1046/j.1365-2168.2000.01303.x

11. Demetriades $D$, Chahwan $S$, Gomez H, et al. Penetrating injuries to the subclavian and axiallary vessels. J Am Coll Surg 1999;188(3):290-295. DOI: 10.1016/s1072-7515(98)00289-0

12. Enamorado-Enamorado J, Egea-Guerrero JJ, Revuelto-Rey J, et al. Left subclavian artery pseudoaneurysm after a traffic accident: a case report. Case Rep Crit Care 2011;2011:1-2.

13. Katras T, Baltazar U, Rush DS, et al. Subclavianarterial injury associated with blunt trauma. Vasc Surg 2001;35(1):43-50. DOI: $10.1177 / 153857440103500108$

14. Lee WA, Matsumura JS, Mitchell RS, et al. Endovascular repair of traumatic thoracic aortic injury: clinical practice guidelines of the society for vascular surgery. J Vasc Surg 2011;53(1):187-192. DOI: 10.1016/j.jvs.2010.08.027

15. Goés Júnior AMO, Maurity MP, Amaral CAC. Controle de danos para lesão de artéria subclávia. J Vasc Bras 2020;19:e20200007. DOI: 10.1590/1677-5449.200007.

16. Elkbuli A, Kinslow K, Dowd B, et al. Subclavian artery injury secondary to blunt trauma successfully managed by median sternotomy with supraclavicular extension: a case report and literature review. Ann Med Surg 2020;54:16-21. DOI: 10.1016/j.amsu.2020.03.012

17. Elkbuli A, Shaikh S, McKenney M, et al. Subclavian artery avulsion following blunt trauma: A case report and literature review. Int J Surg Case Rep 2019;61:157-160. DOI: 10.1016/j.ijscr.2019.07.061

18. Carlos, SF, Góis CC, Machado GF, et al. Traumatismo penetrante dos vasos subclávios: revisão da literatura a propósito de um caso clínico. Revista Portuguesa de Cirurgia, [S.I.], n. 32, pp. 35-41, mar. 2015. ISSN 2183-1165.

19. Costa-Val R, Campos-Christo SF, Abrantes WL, et al. Reflections about civilian cardiovascular trauma admitted to a level 1 trauma center: a prospective study from 1000 cases. Rev Col Bra Cir 2008;35(3): 65. DOI: $10.1590 /$ S0100-69912008000300005

20. HoffSJ, Reilly MK, Merrill WH, et al. Analysis of blunt and penetrating injury of the innominate and subclavian arteries. Am Surg 1994;60(2):151-154. PMID: 8304648.

21. du Toit DF, Coolen D, Lambrechts A, et al. The endovascular management of penetrating carotid artery injuries: longterm follow-up. Eur J Vasc Endovasc Surg 2009;38(3):267-272. DOI: 10.1016/j.ejvs.2009.05.003

22. Sobnach S, Nicol AJ, Nathire $H$, et al. An analysis of 50 surgically managed penetrating subclavian artery injuries. Eur JVasc Endovasc Surg 2010;39(2):155-159. DOI: 10.1016/j.ejvs.2009.10.013

23. du Toit DF, Strauss DC, Blaszczyk M, et al. Endovascular treatment of penetrating thoracic outlet arterial injuries. Eur J Vasc Endovasc Surg 2000;19(5):489-495. DOI: 10.1053/ejvs.1999.1050 